\title{
The invasive apple snail Pomacea canaliculata in Indonesia: a case study in Lake Rawa Pening, Central Java
}

\author{
Ristiyanti M. Marwoto ${ }^{1}{ }^{*}$, Heryanto Heryanto ${ }^{1}$, and Ravindra C. Joshi ${ }^{2}$ \\ ${ }^{1}$ Research Center for Biology, 16911 Gedung Widyasatwaloka, Jalan Raya Jakarta Bogor KM 46 Cibinong, Bogor, Indonesia \\ ${ }^{2}$ CABI Southeast \& East Asia Regional Centre, 43400 Glasshouse A19 (Block G), Serdang, Selangor, Malaysia
}

\begin{abstract}
The occurrence of the invasive apple snail Pomacea canaliculata in Indonesia was first reported in 1984. The species was introduced as an ornamental aquarium pet. Since then, people have begun to culture the snail in ponds usually adjacent to rice fields. When it was realized that the species multiplied rapidly and was a serious pest, this invasive apple snail had already spread widely. There are many cultural methods of controlling and preventing its distribution, but none are effective in keeping them at non-damaging levels. We mapped the distribution of $P$. canaliculata in Indonesia from the MZB's collections as well as literature references and found that the snail invaded almost all large islands, such as Sumatra, Java, Kalimantan, Sulawesi, Maluku, and West Papua. We also studied the impact of $P$. canaliculata on the native apple snails $P$. ampullacea, $P$. scutata, and $P$. virescens in Lake Rawa Pening (a popular tourism destination) as a case study. The results showed that two species of Pila already disappeared from Lake Rawa Pening. Only P. scutata occurs still in the region and was found alive usually in shallow water and rice fields surrounding the lake. To resolve the problem we recommend that cleaning the lake periodically from the invasive aquatic weed Eichhornia crassipes (known to locals as "eceng gondok") by a private company and harvesting the weeds for the local small craft industry by the local fishermen could be an alternative measure to reduce the population of the $P$. canaliculata, as well as collecting $P$. canaliculata for local food or for feeding ducks. Rearranging the number of fish-pens "karamba" and their location in the lake could be seen as an alternative way also for reducing the population of $P$. canaliculata, since the snails lay their egg masses on the bamboo stakes of "karamba." Such rearrangement could make the landscape more attractive for tourism.
\end{abstract}

\section{Introduction}

The apple snail genera Pomacea and Pila are freshwater snails belonging to the family Ampullariidae. The invasive apple snail Pomacea canaliculata has been introduced from South America to southern and eastern Asia and islands of the Pacific, where the species has become a serious agricultural pest causing damage in rice, taro, and other crops $[1,2,3,4]$. It's occurence in Indonesia was reported for the first time in between 1981- 1984 [5, 6]. It was introduced as an ornamental pet in the aquarium trade that people imported from the Philippines [7]. Subsequently, people began to culture the snail in ponds usually adjacent to rice fields for local food especially in Java or for feeding ducks and fish. Within three decades, $P$. canaliculata spread widely across many Indonesian islands starting from Java to Bali, Sumatra, Kalimantan, Sulawesi and West Papua $[4,8]$. Although there are many cultural methods of control and prevent its distribution, none are effective in keeping them at the non-damaging levels, and thus $P$. canaliculata continues to invade new habitats, such as marshes and lakes [4].
The impacts of $P$. canaliculata go beyond being a serious pest to crops, as it has a strong ecological impact on natural wetlands and other aquatic ecosystems $[9,10$, 11,12]. In Hong Kong, $P$. canaliculata devours semiaquatic vegetables, especially watercress (Nasturtium officinale) and water spinach (Ipomoea acquatica). In recent years it has reduced wetland biodiversity by grazing on macrophytes and predation on benthic invertebrates, and altered wetland function by releasing nutrients into the water [13]. According to Carlsson [12] $P$. canaliculata is threatening natural wetland ecosystems in Southeast Asia, Europe and North America, causing eradication of palatable plants, algal bloom, lower water quality, and loss of biodiversity. A study on the effects of P. canaliculata on exotic and native snails in South America by Maldonado \& Martin [14], showed that P.canaliculata is a successful invader and predator of other snails. Investigating the potential ecological impact of $P$. canaliculata on the Thai native apple snail species, Pila scutata, Chaichana \& Sumpan [15], discovered that $P$. canaliculata was superior to $P$. scutata, consuming more food, being non-selective for food, growing better and reaching maturity faster. Similarly, Tan et al. [16] and $\mathrm{Ng}$ et al. [17] reported $P$.

\footnotetext{
Corresponding author: rist001@lipi.go.id
} 
Table 1. N ative apple snail species of Pila recorded from Rawa Pening.

\begin{tabular}{|c|c|c|c|c|c|c|c|c|c|}
\hline Species & 1930 & 1950 & 1972 & 1978 & 1981 & 1984 & 1988 & 1989 & 2018 \\
\hline Pila ampullacea & $\sqrt{ }$ & $\sqrt{ }$ & $\sqrt{ }$ & $\sqrt{ }$ & & $\sqrt{ }$ & $\sqrt{ }$ & $\sqrt{ }$ & \\
\hline Pila virescens & & $\sqrt{ }$ & $\sqrt{ }$ & $\sqrt{ }$ & & $\sqrt{ }$ & $\sqrt{ }$ & & \\
\hline Pila scutata & & $\sqrt{ }$ & $\sqrt{ }$ & $\sqrt{ }$ & $\sqrt{ }$ & $\sqrt{ }$ & $\sqrt{ }$ & & $\sqrt{ }$ \\
\hline
\end{tabular}

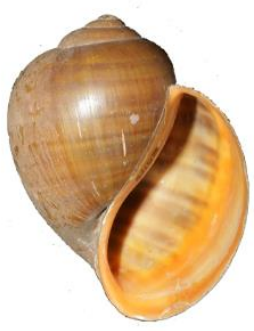

Pila ampullacea

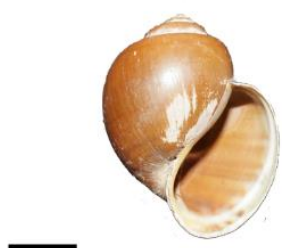

Pila scutata

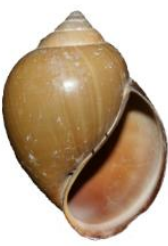

Pila virescens

Fig. 1. Shells of the native apple snail species of the genus Pila (Photo: N.R. Isnaningsih \& M arwoto). Scale $10 \mathrm{~mm}$.

scutata populations declining after the invasion of $P$. canaliculata in Singapore in the 1980s.

Here, we report on a recently conducted case study on the impacts of $P$. canaliculata on the native apple snails (Pila spp.) in Lake Rawa Pening, Central Java, in order to evaluate measures for lake conservation and protecting the native snail species.

Lake Rawa Pening is a semi-natural volcanic lake, about 2.670 ha, situated in Semarang Regency, Central Java, and surrounded by the Ungaran, Merbabu and Telomoyo mountains. This lake is as a famous tourism destination and is managed by the local government of Semarang Regency, including Bawen, Ambarawa, Banyu Biru, Tuntang regions, which is collaborating with local private companies. The deepest part of Lake Rawa Pening is $18 \mathrm{~m}$ and the shallowest about $2-4.7 \mathrm{~m}$ in North West part. It has 14 inlet rivers and only one outlet, River Tuntang [18]. Until now, the lake continues to face many problems, such as the invasion of the aquatic invasive weed (Eichornia crassipes), which is threatening the lake to silt-up, the decaying waste material of fish fodder, as well as the increase in the population of $P$. canaliculata. These problems need solutions, not only to conserve the lake environment, but also to protect the native snails in Rawa Pening that might otherwise disappear from their natural habitats.

Based on the collections of Museum Zoology Bogor (MZB), three native species of Pila have been recorded from Rawa Pening, i.e., P. ampullacea, P. virescens and $P$. scutata, which were collected in the 1930s, 1950s, 1970s, and 1980s (Table 1, Figure 1).

Matricia [19] also reported these three native apple snails (Pila spp.) from Rawa Pening while studying their morphology, anatomy and sex ratio. According to local people, $P$. canaliculata was first observed in Rawa Pening in 1988/1989, and MZB received specimens in 2011. There has been no information about the impact of
P. canaliculata on the three native species of Pila in Rawa Pening. Thus, this study aims to present preliminary data on the status of the native Pila after the invasion of $P$. canaliculata (Figure $1 \& 2$ ).

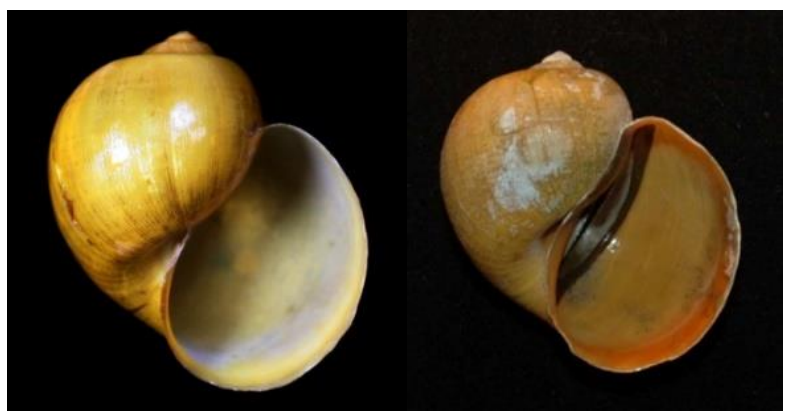

Fig. 2. Shell of the invasive apple snail Pomacea canaliculata (Photo: Eka)

\section{Material and methods}

Apple snails were collected in May, July, and October 2018 and March 2019 (in dry and rainy seasons), from inlets and outlets of 15 rivers (Figure 3 ).

In addition, three more locations were sampled from the middle of Lake Rawa Pening. We spent an hour/site (location) to sample snails, using a sieve or hand picking the snails. The occurrence of ampullariid snails in each location was recorded, including egg clusters (capsules) that are usually attached to the substrate (leaves, stalks, water hyacinth Eichornia crassipes, "karamba", water plants). Habitats were documented by photos. Other information such as secondary data were collected from local people who were either harvesting E. crassipes or collecting fishes or snails, as well as workers in Rawa Pening, who were tourist guides, farmers herding ducks, operators of tourist motor boats, and the owner of local restaurants ("warung"). 


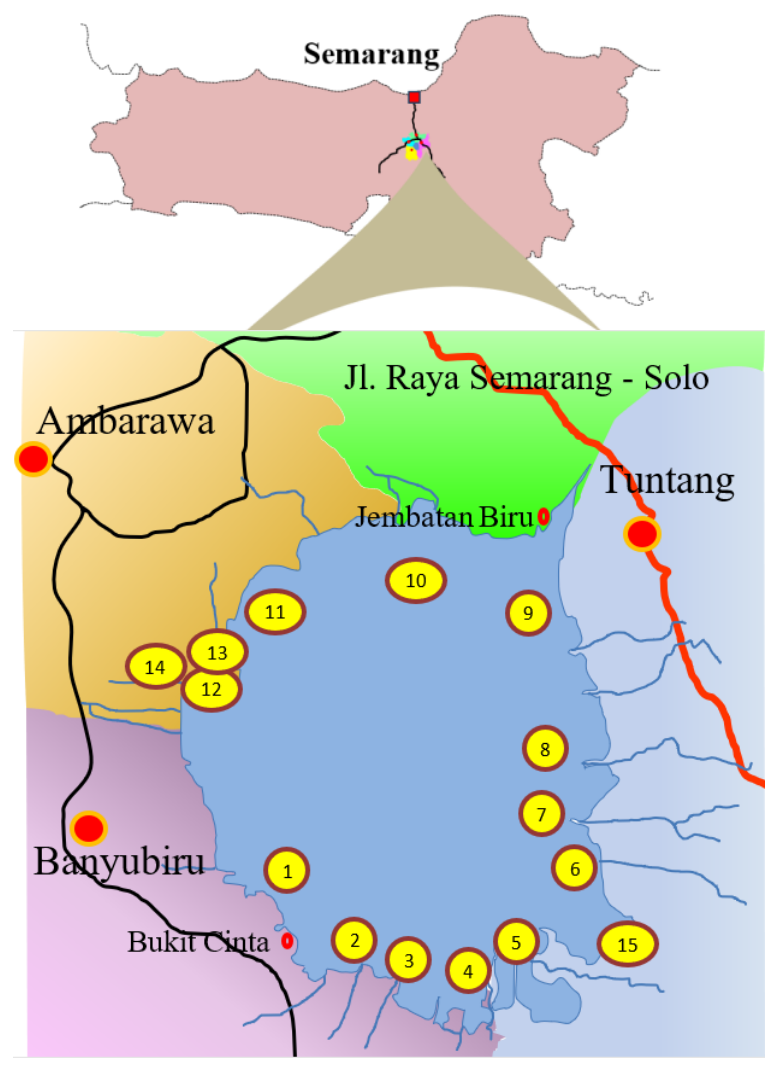

Fig. 3. Map of Lake Rawa Pening with sampling locations. N ote: The name of each location is listed in Table 2. (Prepared by: Heryanto)

Table 2. The occurence of $P$. canaliculata and $P$. scutata in Rawa Pening

\begin{tabular}{llcc}
\hline & Site/Location & P. canaliculata & P. scutata \\
\hline 1. & Gondang & $\sqrt{ }$ & \\
2. & Legi (east site) & $\sqrt{ }$ & \\
3. & Parat & $\sqrt{ }$ & \\
4. Kedungringis & $\sqrt{ }$ & \\
5. Kesongo & $\sqrt{ }$ & $\sqrt{ }$ \\
6. Ngreco & $\sqrt{ }$ & $\sqrt{ }$ \\
7. & Pragunan & $\sqrt{ }$ & $\sqrt{ }$ \\
8. Lo Pait & $\sqrt{ }$ & \\
9. Tuntang & $\sqrt{ }$ & $\sqrt{ }$ \\
10. Asinan & $\sqrt{ }$ & \\
11. Ngaglik & $\sqrt{ }$ \\
12. Kali Gede & $\sqrt{ }$ & \\
13. Panjang & $\sqrt{ }$ & \\
14. Torong & & \\
15. Sraten & $\sqrt{ }$ & \\
\hline
\end{tabular}

\section{Results and discussion}

We only found one species each of the native apple snail (Pila scutata), and the invasive apple snail Pomacea canaliculata in Rawa Pening. P. canaliculata was found at all sampled localities, while $P$. scutata was found at only six localities in Rawa Pening (Table 2). The eggs of $P$. canaliculata are bright pink in color, with $300-850$ eggs per cluster, and easily recognizable sticking to aquatic plants (E. crassipes) and boat hulls (Figure 3C). The adult snails were also found among the roots or stalks of E. crassipes or crawling on the muddy substrate. As mentioned by $M$ arwoto et al. [4], $P$. canaliculata was found to be 'everywhere', and during the dry season even in small and shallow mud-holes or under E. crassipes. Chaichana \& Sumpan [15] stated that $P$. canaliculata is non-selective in feeding, compared to $P$. scutata which feeds only on preferred plants. This statement is supported by our study in Rawa Pening, which found $P$. canaliculata in all kinds of habitats.

In contrast to $P$. canaliculata, the native snail $P$. scutata was found in different habitats at only six sites (sampled locations), i.e., Kesongo, Ngreco, Pragunan, Lo Pait, Ngaglik, and Kali Gede, which were usually near rice fields, in shallow water with muddy substrate and sheltered areas. The eggs are white, with 8 to 20 eggs per cluster, and are attached among the stalks of $E$. crassipes, near the water surface (Figure $4 \mathrm{~B}$ ). This matches the habitat preference of $P$. scutata as described by Tan et al. [16]: the snail appears to favor shady, sheltered places, it is often found among vegetation, and the egg clusters are deposited above the waterline, usually in depressions in the damp soil, and sheltered spots under the vegetation. The number of eggs per cluster of $P$. scutata is lower compared to that of $P$. canaliculata, so there are more hatched eggs as well as young snails in $P$. canaliculata.

Only $P$. scutata still continues to survive and live together with $P$. canaliculata, while the two other native apple snail species ( $P$. ampullacea and $P$. virescens) no longer exist in Rawa Pening. From the confirmed dates of the occurrence of all three species of Pila in Rawa Pening (Table 1), it seems that $P$. ampullacea and $P$. virescens have disappeared after 1988 and thus after the introduction of $P$. canaliculata into this area. When $P$. canaliculata shares the habitat with $P$. scutata, it is likely that P.canaliculata displaces P.scutata. Food competitions seems to be the cause, as food consumpsion of $P$. canaliculata tends to be higher and it also has a faster growth rate compared to $P$. scutata [15]. We did not find any egg clusters of $P$. ampullacea, which are usually laid on the stems of aquatic plants above the water line. The same was true for the absence of $P$. virescens eggs and adult snails from the sampling locations. The eggs of $P$. ampullacea, $P$. scutata and $P$. virescens are easy to recognize. They differ in shape, color, size, as well as the total number of eggs per cluster $[16,20]$. Lake Rawa Pening, which is covered by $E$. crassipes, very densely in some parts, might not provide a suitable habitat for $P$. ampullacea any more, for example, as there are no more high aquatic plants, which are important for the snail to lay its eggs upon. This is suggested by our observations in ponds of Bogor Botanical Garden, where many aquatic plants are loaded with the eggs of $P$. ampullacea (unpublished data, see Figure 4A). The eggs of $P$. ampullacea are usually attached to aquatic plants such as kirai palm (Metroxylon rumphii), and Cyprus papyrus, Hanguana malaya, Sagittaria lancifolia, Thali geniculata, about $20-75 \mathrm{~cm}$ above the water level, with $15-50$ or more eggs/cluster [21]. We do not have any data for the aquatic plants from 


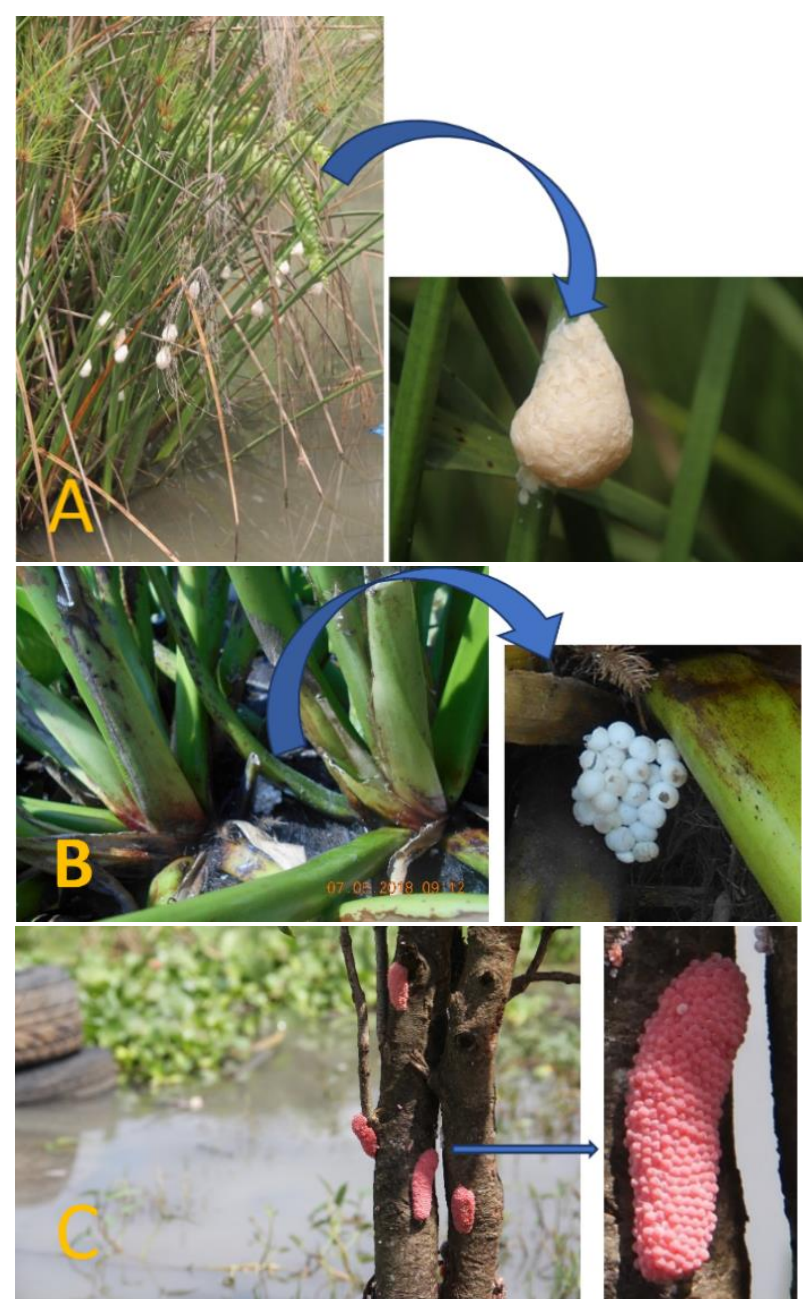

Fig 4. A pple snail egg clusters: A. Pila ampullacea, B. Pila scutata, C. Pomacea canaliculata (Photo: R.M. M arwoto)

Rawa Pening, but no egg clusters of $P$. ampullacea were found at the locations sampled that were covered with $E$. crassipes.

Sedimentation and silting up caused by E. crassipes is a very serious problems in Rawa Pening. A revitalisation program by dredging the mud from the lake has been planned by the local government. Tons of $E$. crassipes were picked up from the lake together with the mud using a special crane and then dried for cleaning the lake, and thousands of $P$. canaliculata and its egg masses have been trapped in the crane, which will die because of desiccation from heat. Harvesting $E$. crassipes for handicrafts seems to be useful for reducing the population of $P$. canaliculata as well as collecting the snails to feed ducks and fishes, and these activities should be recommended to natives.

Lake Rawa Pening constitutes a good case study for assessing the impacts of $P$. canaliculata on native apple snail species (Pila spp.). More detailed studies on the wetland ecology and population dynamics of invasive and native apple snails in Rawa Pening are needed, as basic data is needed to reduce the impacts of $P$. canaliculata on natural ecosystems and the native apple snail species.

\section{Conclusion}

In Rawa Pening the invasive apple snail ( $P$. canaliculata) has negative impacts leading to loss of the two native apple snail species ( $P$. ampullacea and $P$. virescens).

Pila scutata is the only native apple snail species still occurring in Rawa Pening, but it is threatened. Harvesting water hyacinth (Eichornia crassipes) and collecting adult snails $P$. canaliculata for feeding ducks and fish could be an alternatives solution for reducing the population of invasive apple snails in Rawa Pening. Dredging mud and picking-up E. crassipes periodically will also be effective in preventing Lake Rawa Pening from silting-up, sedimentation and drying-out.

The study in Rawa Pening is a part of the Fauna Java project supported by the Research Center for Biology-LIPI through the Program of DIPA 2018/2019. Our sincere thanks to Alfiah for collecting the snails in Rawa Pening, and to Riena Prihandini for preparing the specimens (Laboratory of Malacology, Museum Zoology Bogor, Research Center for Biology- LIPI).

\section{References}

1. R. H. Cowie, K. A. Hayes, S. C. Thiengo, Global Advances in Ecology and Management of Golden Apple Snails (PhilRice, Nueva Ecija, 2006)

2. R. C. Joshi, L. S. Sebastian, Global advances in ecology and management of golden apple snails (PhilRice, Nueva Ecija, 2006)

3. R. H. Cowie, K. A. Hayes, S. C. Thiengo, Biology and Management of Invasive Apple Snails (PhilRice, Nueva Ecija, 2017) https://www.cabi.org/isc/FullTextPDF/2017/201733 54475.pdf

4. R. M. Marwoto, N. R. Isnaningsih, R. C. Joshi, Agriculture for Development, 35, 41-48 (2018) https://www.cabi.org/isc/FullTextPDF/2019/201930 44933.pdf

5. O. Mochida, Micronesica Supplement, 3, 51-62 (1991)

6. K.A. Hayes, R.C. Joshi, S.C. Thiengo, R.H. Cowie, Divers Distrib, 14, 701-712 (2008) https://doi.org/10.1111/j.1472-4642.2008.00483.x

7. R. M. Marwoto, Treubia, 29, 275-276 (1988)

8. R. M. Marwoto, N. R. Isnaningsih, Biotropia, 18, 123-128(2011) http://dx.doi.org/10.11598/btb.2011.18.2.247

9. N. O. L. Carlsson, C. Brönmark, L-A. Hanson, Ecology, 85, 6 (2004) https://doi.org/10.1890/03-3146

10. L. T. P. Nghiem, T. Soliman, D. C. J. Yeo, H.T.W. Tan, T. A. Evans, J. D. Mumford, PLoS ONE, 8 (2013) https://doi.org/10.1371/journal.pone.00712551

11. F.G. Horgan, A.M. Stuart, E.P. Kudavidanage, Acta Oecol, 54, 90-100 (2014).

DOI : $\underline{10.1016 / \text { j.actao.2012.10.002 }}$ 
12. N. O. Carlsson, Biology and Management of Invasive Apple Snails (PhilRice, Nueva Ecija, 2017). https://www.cabi.org/isc/FullTextPDF/2017/201733 54482.pdf

13. Ip. K. L. Kelvin, J-W. Qiu, Biology and Management of Invasive Apple Snails (PhilRice, Nueva Ecija, 2017). https://repository.hkbu.edu.hk/hkbu staff publicatio $\underline{\mathrm{n} / 6401}$

14. M. A. Maldonado, P. R. Martin, Curr Zool, 65, 225235 (2019) https://doi.org/10.1093/cz/zoy060

15. R. Chaichana, T. Sumpan, ScienceAsia, 40, 11-15 (2014)

DOI: $10.2306 /$ scienceasia1513-1874.2014.40.011
16. S. K. Tan, Y. L. Lee, T. H. Ng, NiS, 6, 135-141 (2013)

17. T.H. Ng, S.K. Tan, M.E.Y. Low, NiS, 7, 31-47 (2014)

18. T. R. Soeprobowati, Bioma, 14, 75-78 (2012) https://doi.org/10.14710/bioma.14.2.78-84

19. T. Matricia, Anatomi, morfologi, dan nisbah kelamin beberapa jenis keong gondang di Rawa Pening Jawa Tengah (IPB, Bogor, 1985)

20. W. S. S. van Benthem Jutting, Treubia, 23, 259-477 (1956)

21. M. Djajasasmita, Berita Biologi, 3, 342-346 (1987) 